Article

\title{
Synthesis, Redox Properties and Antibacterial Activity of Hindered Phenols Linked to Heterocycles
}

\author{
Vladimir N. Koshelev, Olga V. Primerova *, Stepan V. Vorobyev (10 and Ludmila V. Ivanova \\ Department of organic chemistry and petroleum chemistry, Gubkin Russian State University of Oil and Gas, \\ Leninsky av. 65, 119991 Moscow, Russia; Koshelev.V@gubkin.ru (V.N.K.); Vorstepan@yandex.ru (S.V.V.); \\ Ivanova.1@gubkin.ru (L.V.I.) \\ * Correspondence: primerova92@yandex.ru; Tel.: +7-926-329-63-27
}

Academic Editors: Paola Di Donato and Brigida Silvestri

Received: 21 April 2020; Accepted: 19 May 2020; Published: 20 May 2020

\begin{abstract}
A series of benzotriazole, cyclic amides and pyrimidine derivatives, containing 2,6-di-tert-butyl-phenol fragments, were synthesized. The redox properties of obtained compounds were studied using the cyclic voltammetry on a platinum electrode in acetonitrile. The oxidation potentials of all substances were comparable to those of BHT. The obtained compounds were tested for their antibacterial activity, and $N$-(2-(3,5-di-tert-butyl-4-hydroxyphenyl)-2-oxoethyl)isatin ( $32 \mu \mathrm{g} / \mathrm{mL})$ exerted good activity against Staphylococcus aureus.
\end{abstract}

Keywords: hindered phenols; heterocycles; antioxidants; antibacterial activity

\section{Introduction}

Oxidative destruction plays an important role in biochemical processes. Free radicals and reactive oxygen species induce the oxidative damage of cell membranes, lipids, proteins, and DNA repair system breakdown that is connected with many degenerative diseases, such as cancer, atherosclerosis, Alzheimer's disease [1-3]. The main defense mechanism of the body is the use of antioxidants, aiming to scavenge free radicals and inhibit oxidative stress processes, because of their ability to break the chain process of free radical oxidation [4]. They either naturally generated in situ (endogenous antioxidants), or are externally provided through foods (exogenous antioxidants) [5]. Sterically hindered phenols have been used as antioxidant agents for more than half a century [6,7]. One of the best known representatives of this class of antioxidant agents is 2,6-di-tert-butyl-4-methylphenol (butylated hydroxytoluene, BHT), primarily used in food, cosmetics and pharmaceuticals [5,8-10], and its derivatives are widely used in the oil industry [11,12]. The efficacy of 2,6-di-tert-butylphenols as inhibitors of oxidative destruction of hydrocarbons is determined by the nature of ortho-alkyl groups and the group in the para-position of the aromatic ring, which affects the stability of the phenoxyl radicals generated during oxidation [13-15].

In recent years, a great deal of effort has been devoted to finding multipotent antioxidants, substances which combine antioxidant activity and other pharmacological effects: anti-inflammatory, anticoagulant, anticarcinogenesis activities [16].

Among them, a large number of pharmacologically active substances exhibiting a wide variety of chemotherapeutic activity have been synthesized on the basis of sterically hindered phenols and various heterocyclic compounds.

Anti-inflammatory activity is most often found in compounds of these series [17-19]. The drugs containing BHT or 2,6-di-tert-butylphenol and heterocycles used to treat inflammatory conditions, which include tazofelone, darbufelone, prifelone, and tebufelone, are available commercially [20].

Additionally, many heterocycles, containing 2,6-di-tert-butylphenol fragment, that are active against various types of cancer, have been found. Experimental data report on the cytotoxicity against 
tumor lines of epithelioid carcinoma of the cervix uteri (M-Hela) and breast adenocarcinoma (MCF-7) of 2,6-diaminopyridine derivatives [21]. Symmetric S-BHT derivatives containing 1,3,4-thiadiazole fragments showed antioxidant potency and potential to be useful and promising selective agents against breast and colon cancer [22].

It is known that hindered phenols, which are part of natural extracts and synthetic particles, exhibit antibacterial properties. [23-27]. However, the number of antibacterial agents based on heterocycles with hindered phenol fragments is not so wide. In recent years, metal complexes of phthalocyanines and azomethines containing fragments of 2,6-di-tert-butylphenol have been found to exhibit anti-bacterial activity against Gram-negative bacteria E. coli [28-30].

Moreover, 2,3-dihydropyrrolo [1,2-a]imidazole I showed high antimicrobial activity when tested for biocidal activity in jet fuels [31]. Compound II was found to have high protistocidal activity, 10-15 times greater than that of Baycox, which is used for the treatment of coccidiosis in poultry [32]. 1,3,4-Thiadiazole III (Figure 1) [33] exhibited a high degree of protection in extending the lifespan of nematodes following $S$. aureus infection.
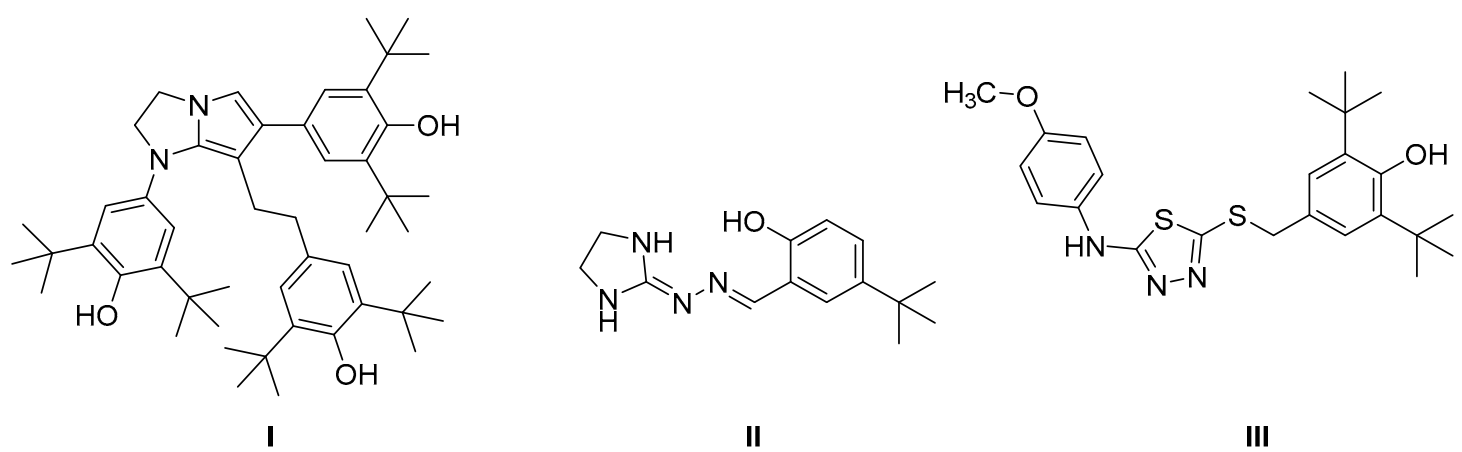

Figure 1. Examples of substances, exhibiting antibacterial activity.

To sum up, multipotent antioxidants with antibacterial properties are of great interest; in particular, for the food industry, because both effects are highly desirable to keep foods as fresh as possible. Promising results showed above prompted us to investigate the chemical diversity of heterocyclic substituents of hindered phenol, which have not yet been explored. The most up-to-date rational design approach for multipotent antioxidants is to connect an antioxidant group with other pharmacophores [16]. Heterocycles, which we incorporated into the structure of antioxidant: benzotriazole, phthalimide, isatin, succinimide, 2,4-dihydroxypyrimidine, 3,4-dihydropirimidin-2(1H)-one, are the basis of antibacterial agents [34-39] and, in addition, have an NH group available for modification in the cycle. The antioxidant properties can both improve and decrease quite significantly with the introduction of a substituent in the phenol structure [40]; therefore, it is necessary to study the antioxidant properties of the obtained compounds.

The aim of this study was to synthesize new multipotent antioxidants, coupling 2,6-di-tertbutylphenol and a series of heterocycles. The compounds synthesized were assayed for antioxidant and antibacterial activity.

\section{Results and Discussions}

\subsection{Synthesis}

The preparation of the target compounds is outlined in the following; Schemes 1-3. Initially, 2-bromo-1-(3,5-di-tert-butyl-4-hydroxyphenyl)ethanone 1 was conveniently obtained from 2,6-di-tert-buthylphenol through acylation with acetyl chloride [41] and subsequent bromination [42]. 


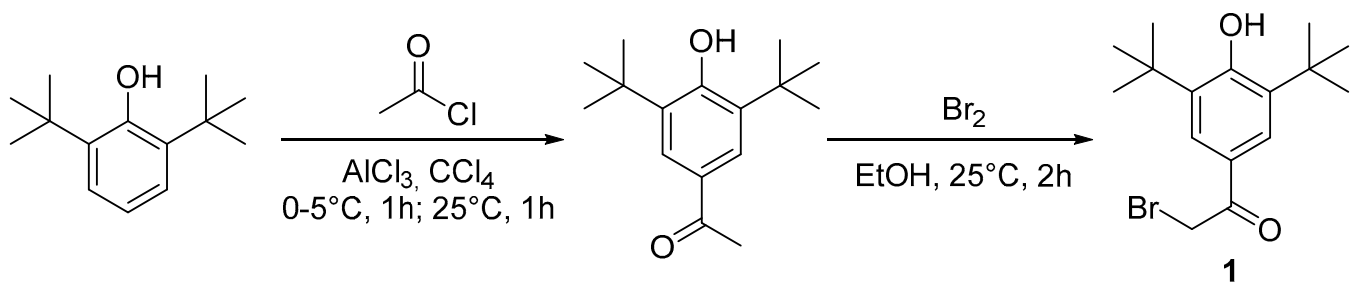

Scheme 1. Scheme of preparation of bromo-acetophenon 1.

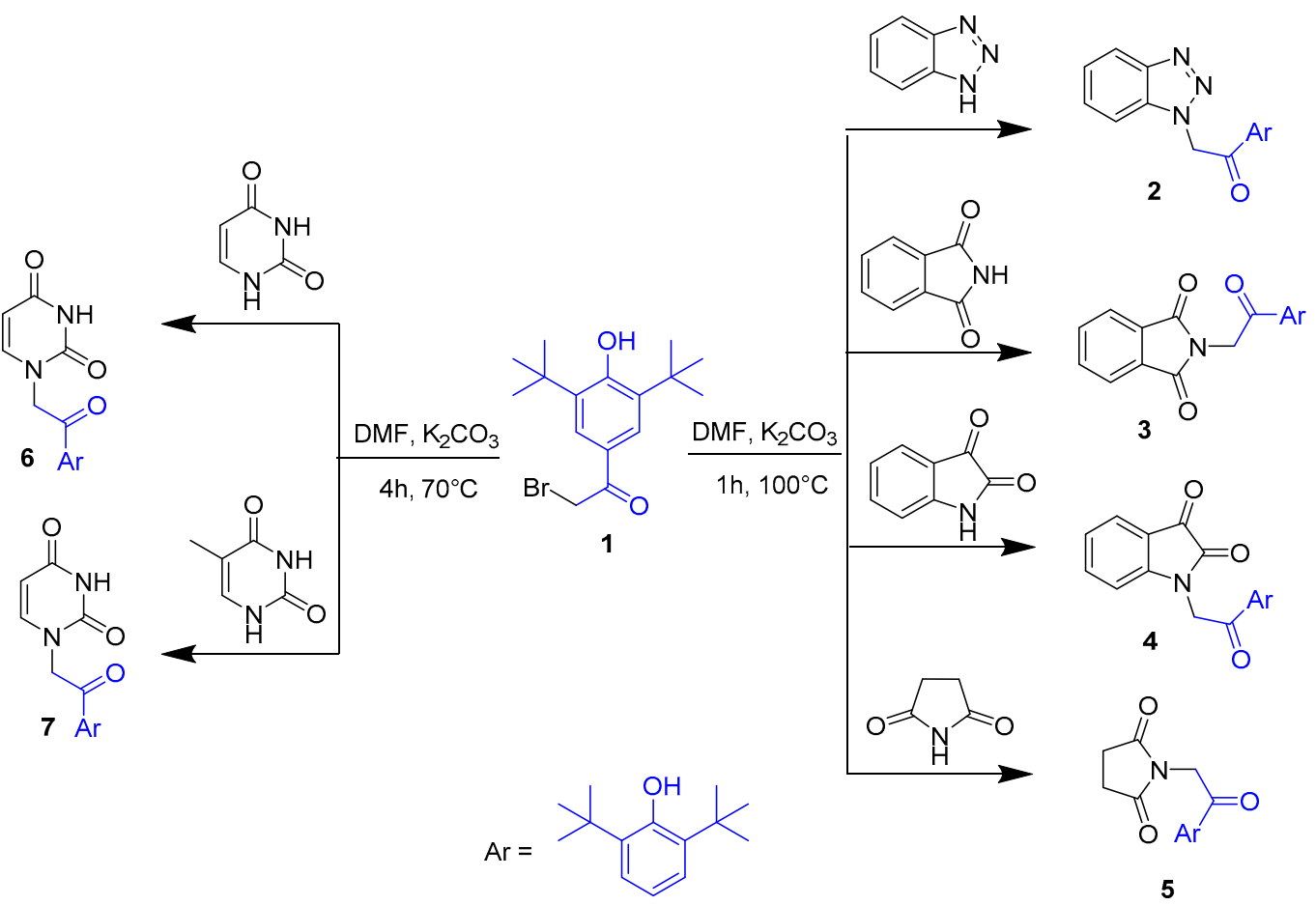

Scheme 2. Scheme of preparation of compounds $2-7$.<smiles>CC(C)(C)c1cc(C=O)cc(C(C)(C)C)c1O</smiles>

$$
\begin{aligned}
& \mathrm{Xa}: \mathrm{R}=\mathrm{OEt}, \mathrm{X}=\mathrm{O} \\
& \begin{array}{l}
\text { 9b: } \mathrm{R}=\mathrm{OEt}, \mathrm{X}=\mathrm{S} \\
9 \mathrm{c}: \mathrm{R}=\mathrm{Me}, \mathrm{X}=\mathrm{S}
\end{array}
\end{aligned}
$$<smiles>[R]C(=O)C1=C(C)NC([X])=NC1c1cc(C(C)(C)C)c(O)c(C(C)(C)C)c1</smiles>

Scheme 3. Scheme of preparation of 3,4-dihydropirimidin-2(1H)-one $\mathbf{9 a}$ and thiones $\mathbf{9} \mathbf{b}-\mathbf{c}$.

The further synthesis entailed an alkylation heterocycles: benzotriazole, phtalimide, isatin, succinimide, uracil and 5-methyluracil (thymine) by bromo-acetophenon 1 in DMF with $\mathrm{K}_{2} \mathrm{CO}_{3}$. The reaction was carried out at $100{ }^{\circ} \mathrm{C}$ for an hour, with the exception of interaction 1 with uracil and methyluracil: in these cases, the reaction gave black resin, and optimal conditions to obtain compounds 6 and 7 were found to be $70^{\circ} \mathrm{C}$ and $4 \mathrm{~h}$.

In the ${ }^{1} \mathrm{H}$ NMR spectra of compounds $2-5$, all peaks, corresponding to phenol fragment are observed: the singlet peak near $5.83 \mathrm{ppm}$ is attributed to the $\mathrm{O}-\mathrm{H}$ of the hindered phenol, peaks at $7.82-7.88 \mathrm{ppm}$ with the integration of two protons was assigned to the two symmetrical aromatic ring protons, singlet peaks at $4.93-5.17$, corresponding to $\mathrm{CH}_{2}-\mathrm{N}$ protons, and there are no peaks of $\mathrm{NH}$-protons of starting cyclic imides and benzotriazole. 
During the alkylation of uracil and its derivatives, the attack of the alkylating reagent is possible in two directions: N-1 atom and N-3 atom [43]. The structure of compounds 6 and 7 was also confirmed with HMBC and HSQC spectra (Figure 2 for 7 and Supplementary Material for 6). The spectrum contains correlation peaks between C-3 and H-6, C-2 and H-6, C-6 and H-2. This indicates that bromo-acetophenone 1 attacked the $\mathrm{N}-1$ atom of 5-methyluracil and uracil.

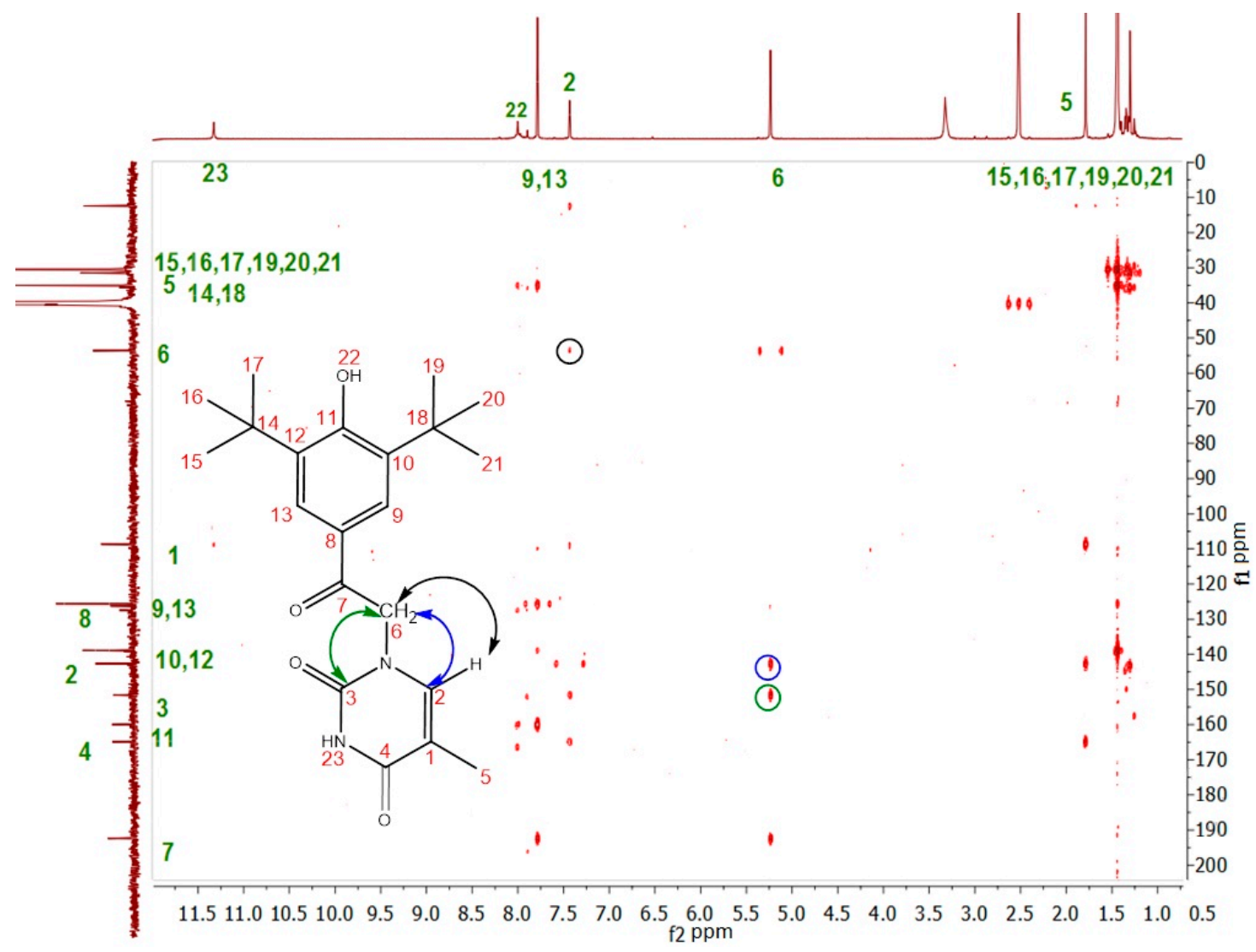

Figure 2. NMR ${ }^{1} \mathrm{H}_{-}{ }^{13} \mathrm{C}$ HMBC spectra of 7.

To expand the range of pyrimidine derivatives, a number of 3,4-dihydropyrimidine (thiones)ones with a hindered phenol fragment were obtained by Biginelli reaction, according to Scheme 3.

The most common catalysts reported for the Biginelli reaction are mineral acids $\left(\mathrm{H}_{2} \mathrm{SO}_{4}[44]\right.$, $\mathrm{HCl}$ [45], TFA [46]), Lewis acids $\left(\mathrm{CoCl}_{2}, \mathrm{ZnCl}_{2}\right.$ [47]), and other catalytic systems: $\mathrm{FeCl}_{3}+\mathrm{HCl}$ [48], $\mathrm{TMSCl}+\mathrm{NaI}$ [49]. However, in our hands, the products were not obtained when all these conditions were employed. Previously, researchers from the Vorozhtsov Novosibirsk Institute of Organic Chemistry have synthesized compound 9a in the presence of $\mathrm{FeCl}_{3} \bullet 6 \mathrm{H}_{2} \mathrm{O}$ as a catalyst [50]. These conditions (with some correction) turned out to be suitable for the synthesis of compounds $9 \mathbf{a}-\mathbf{c}$ with yields $55-64 \%$.

In the ${ }^{1} \mathrm{H}$ NMR spectra of compounds $9 a-c$, there are no peaks in the region of $10.4 \mathrm{ppm}$ corresponding to the proton of the aldehyde group. Peaks at 7.02-7.66 ppm corresponding to the proton of the phenolic group are present in all spectra. Peaks of NH protons in the spectrum of derivatives with $\mathrm{C}=\mathrm{S}$ groups are shifted to a higher-field $(7.2-8 \mathrm{ppm})$, in comparison with derivatives with the $\mathrm{C}=\mathrm{O}$ group $(7.8-9 \mathrm{ppm})$.

\subsection{Redox Properties}

The antioxidant activity of phenolic compounds is revealed, mainly due to their redox properties, which can play an important role in absorbing and neutralizing free radicals, quenching reactive oxygen species, such as singlet and triplet oxygen, or decomposing peroxides [51]. Absolute values of oxidation 
potentials characterize the reducing ability of antioxidant agents and therefore the manifestation of their antioxidant effect [6]. Cyclic voltammetry is one of the most robust methods for studying the redox properties of compounds, as well as evaluating their antioxidant ability [52-54].

Cyclic voltammogrames of synthesized compounds exhibit one irreversible two-electron peak corresponding to the phenolic fragment oxidation in the anodic region. Table 1 shows the oxidation potentials of the studied compounds. In the case of substances 2-7 the peak potentials are shifted to a more positive region compared to the BHT, which indicates the enhancement of the electron-windrowing character of the substituent in the para-position to the hydroxy group. The compound 5 , which contains a succinimide fragment, has the highest value of Epa (oxidation potential). Epa of the other compounds are close to those of BHT. The oxidation potentials of compounds $\mathbf{9 a}-\mathbf{c}$ are lower than those of BHT, for two possible reasons.

Table 1. Oxidation potentials (Epa) of compounds 2-7, 9a-c.

\begin{tabular}{ccccccccccc}
\hline № & $\mathbf{2}$ & $\mathbf{3}$ & $\mathbf{4}$ & $\mathbf{5}$ & $\mathbf{6}$ & $\mathbf{7}$ & $\mathbf{9 a}$ & $\mathbf{9 b}$ & $\mathbf{9 c}$ & BHT \\
\hline Ера, V & 1.54 & 1.57 & 1.52 & 1.68 & 1.61 & 1.58 & 1.49 & 1.48 & 1.46 & 1.52 \\
\hline
\end{tabular}

Firstly, compounds 2-7 contain the electron-withdrawing carbonyl group, which decreases the efficacy of phenolic fragment [55]. Notably, the oxidation potential, however, is still comparable to those of BHT. Secondly, the $\mathrm{CH}$ group of the pyridine ring affects the oxidation potential; it contributes to a shift in the electron density due to the effect of hyperconjugation with the benzene ring [56]. Furthermore, the products of oxidation of compounds $\mathbf{9 a}-\mathbf{c}$ can be stabilized by the heterocyclic ring, connected directly to the phenolic one [57].

Furthermore, slight differences in the oxidation potentials of compounds $9 a, 9 b$ and $9 c$ are observed. Compounds $9 \mathbf{b}$ and $9 \mathrm{c}$ have exhibited lower value of anodic potential peak compared to compound 9a, due to the strongest electron-withdrawing effect of the ester group in the pirimidin ring, compared to the acetyl group in compounds $\mathbf{9 b}$ and $\mathbf{9 c}$. This can be explained by the fact that the acceptor effect of the thionic group of the pyrimidine ring is weaker than that of the carbonyl group. At the same time, the electron-withdrawing effect of the acetyl group is weaker than of the ester group, which explains the lowest oxidation potential of compound 9c.

\subsection{Antibacterial Activity}

The antibacterial activity of the synthesized compounds was tested against five strains of pathogenic bacteria: Staphylococcus aureus (SA), Escherichia coli (EC), Klebsiella pneumonia (Kp), Acinetobacter baumannii (Ab), Pseudomonas aeruginosa (Pa). The investigation was carried out in the international laboratory CO-ADD based in Institute of Molecular Biology, University of Queensland (Brisbane, Australia). Test substances were administered at a concentration of $32 \mu \mathrm{g} / \mathrm{mL}$. Substance may be considered active if inhibition values equal to or above $80 \%$ of inhibition for either replicate ( $\mathrm{n}=2$ on different plates). The antibacterial activity for all studied compounds is given in Table 2 . The product of isatin alkylation 4 exerted good activity against Staphylococcus aureus. Although there is no explicit correlation between antioxidant activity and antibacterial capacity of investigated substances, we can suppose that the activity of compound 4 is linked with isatin moiety, which is known to possess antibacterial activity $[58,59]$. This compound was selected as "hit" and tested for the minimum inhibitory concentration (MIC), cytotoxicity against human embryonic kidney cells and haemolytic activity. It was shown that compound 4 does not inhibit the growth of bacteria in smaller concentrations as well as the one of human cells. 
Table 2. Inhibition of bacterial growth, $\%$.

\begin{tabular}{cccccc}
\hline Sample & $\mathbf{S a}$ & $\mathbf{E c}$ & $\mathbf{K p}$ & $\mathbf{P a}$ & $\mathbf{A b}$ \\
\hline $\mathbf{2}$ & 17.42 & 4.05 & 14.45 & 8.08 & 18.75 \\
$\mathbf{3}$ & 16.81 & 7.56 & 20.34 & 10.92 & 12.56 \\
$\mathbf{4}$ & 96.6 & -2.04 & 13.96 & 0.04 & 41.59 \\
$\mathbf{5}$ & -8.94 & 2.53 & 3.38 & 13.97 & 2.47 \\
$\mathbf{6}$ & 20.06 & 7.29 & 10.32 & 18.62 & -1.13 \\
$\mathbf{7}$ & 14.9 & 6.12 & 10.36 & 13.6 & 0.53 \\
$\mathbf{9 a}$ & 19.13 & 8.94 & 9.46 & 18.08 & -5.78 \\
$\mathbf{9 b}$ & 26.31 & -2.72 & -3.54 & -9.39 & -11.19 \\
\hline
\end{tabular}

\section{Materials and Methods}

\subsection{General Information}

The NMR ${ }^{1} \mathrm{H}$ and ${ }^{13} \mathrm{C}$ spectra of solutions in DMSO- $\mathrm{d}_{6}$ and $\mathrm{CDCl}_{3}$ were recorded on a Bruker AM-300 spectrometer (Karlsruhe, Germany). All experiments were performed according to the standard methods of Bruker. Chemical shifts were reported relative to $\mathrm{Me}_{4} \mathrm{Si}$. The values of SSCCs are given in $\mathrm{Hz}$. The mass spectra were recorded on an MS-30 Kratos device (Eu, $70 \mathrm{eV})$. A peak of the molecular ion $\mathrm{M}^{+}$was observed for all synthesized compounds. The melting points of the compounds obtained were determined in an open capillary. Elemental analysis was carried out using Elemental analyzer Vario micro cube (Langenselbold, Germany). The course of reactions and purity of the compounds obtained was monitored by TLC on silica gel plates in a 10:1 benzene-ethanol (10:1 chloroform-ethanol also can be used) solvent system.

\subsection{Synthesis and Analytical Data of Preparated Compounds}

\subsubsection{Synthesis of Compounds 2-5}

A solution of bromoacetophenone $1(3 \mathrm{mmol})$ with benzotriazole, phthalimide, isatin or succinimide $(3 \mathrm{mmol})$ and anhydrous $\mathrm{K}_{2} \mathrm{CO}_{3}(9 \mathrm{mmol})$ was stirred for $1 \mathrm{~h}$ at $10{ }^{\circ} \mathrm{C}$ in $15 \mathrm{~mL}$ of DMF. After cooling, it was poured into water and the precipitate was filtered off. The precipitate was boiled first in hexane, then in water. The resulting crystals were recrystallized from an appropriate solvent.

2-(1H-1,2,3-benzotriazol-1-yl)-1-(3,5-di-tert-butyl-4-hydroxyphenyl)ethanone 2. White solid. Yield 71\%. m.p. 166-167 ${ }^{\circ} \mathrm{C}\left(\mathrm{EtOH}: \mathrm{H}_{2} \mathrm{O} 3: 1\right) . \mathrm{NMR}^{1} \mathrm{H}\left(\mathrm{DMSO}_{-} \mathrm{d}_{6}, \delta, \mathrm{ppm},{ }^{3} \mathrm{~J}_{\mathrm{HH}}, \mathrm{Hz}\right): 1.43\left(\mathrm{~s}, 18 \mathrm{H}, 2\left(\mathrm{CH}_{3}\right)_{3}\right) ; 6.50(\mathrm{~s}, 2 \mathrm{H}$, $\left.\mathrm{CH}_{2} \mathrm{~N}\right) ; 7.41(t, 1 \mathrm{H}, 5-\mathrm{C} \mathrm{CH}$ in benzotriazole, $J=8.1) ; 7.52(\mathrm{t}, 1 \mathrm{H}, 6-\mathrm{C} \mathrm{CH}$ in benzotriazole, $J=8.1)$; $\overline{7.79}(\mathrm{~d}, 1 \mathrm{H}, 4-\mathrm{C} \mathrm{CH}$ in benzotriazole, $J=10.3), 7.88(\mathrm{~s}, 2 \mathrm{H}, \mathrm{Ar}), 8.06(\mathrm{~d}, 1 \mathrm{H}, 7-\mathrm{C} \mathrm{CH}$ in benzotriazole, $J=8.06) . \mathrm{NMR}^{13} \mathrm{C}\left(\mathrm{DMSO}_{6} \mathrm{~d}_{6}, \delta, \mathrm{ppm}\right): 30.4 ; 35.0 ; 54.2 ; 111.4 ; 118.3 ; 119.5 ; 124.2 ; 126.0 ; 126.2 ; 127.6$; 134.5; 138.8; 145.6; 160.3; 191.5. Elemental analysis found: $\mathrm{C}, 72.15 ; \mathrm{H}, 7.65 ; \mathrm{N}, 11.41$. Calculated for $\mathrm{C}_{22} \mathrm{H}_{27} \mathrm{~N}_{3} \mathrm{O}_{2}: \mathrm{C}, 72.30 ; \mathrm{H}, 7.45 ; \mathrm{N}, 11.50$.

2-[2-(3,5-Di-tert-butyl-4-hydroxyphenyl)-2-oxoethyl]-1H-isoindole-1,3-(2H)-dione 3. White solid. Yield 67\%. m.p. ${ }^{188-189}{ }^{\circ} \mathrm{C}$ (benzene). NMR ${ }^{1} \mathrm{H}\left(\mathrm{DMSO}_{6} \mathrm{~d}_{6}, \delta, \mathrm{ppm},{ }^{3} \mathrm{~J}_{\mathrm{HH}}, \mathrm{Hz}\right): 1.41\left(\mathrm{~s}, 18 \mathrm{H}, 2\left(\mathrm{CH}_{3}\right)_{3}\right)$; $5.17\left(\mathrm{~s}, 2 \mathrm{H}, \mathrm{CH}_{2} \mathrm{~N}\right) ; 7.82\left(\mathrm{~s}, 2 \mathrm{H}, \mathrm{Ar}\right.$ in phenol); $7.90\left(\mathrm{~m}, 4 \mathrm{H}, \mathrm{Ar}\right.$ in phtalimide). NMR ${ }^{13} \mathrm{C}\left(\mathrm{DMSO}^{\mathrm{d}} \mathrm{d}_{6}, \delta\right.$, ppm): $30.4\left(2\left(\mathrm{CH}_{3}\right)_{3}\right) ; 35.1 ; 44.7\left(\mathrm{CH}_{2} \mathrm{~N}\right) ; 109.6$ (phtalimide); $123.8 ; 126.0$ (phtalimide); $132.1 ; 135.2 ; 138.9$ (phtalimide); 160.2 (Ar phtalimide); 168.1 (2C=O in imide); $191.3(\mathrm{C}=\mathrm{O})$. Elemental analysis found: $\mathrm{C}$, 73.16; $\mathrm{H}, 7.08 ; \mathrm{N}$, 3.51. Calculated for $\mathrm{C}_{24} \mathrm{H}_{27} \mathrm{NO}_{4}$ : C, 73.26; $\mathrm{H}, 6.92 ; \mathrm{N}, 3.56$.

1-[2-(3,5-Di-tert-butyl-4-hydroxyphenyl)-2-oxoethyl]-1H-indole-2,3-dione 4. Yellow solid. Yield 60\%. m.p. 195-196 ${ }^{\circ} \mathrm{C}\left(\mathrm{EtOH}: \mathrm{H}_{2} \mathrm{O} 2: 1\right) . \mathrm{NMR}^{1} \mathrm{H}\left(\mathrm{DMSO}_{-} \mathrm{d}_{6}, \delta, \mathrm{ppm},{ }^{3} \mathrm{~J}_{\mathrm{HH}}, \mathrm{Hz}\right): 1.41\left(\mathrm{~s}, 18 \mathrm{H}, 2\left(\mathrm{CH}_{3}\right)_{3}\right) ; 5.08(\mathrm{~s}, 2 \mathrm{H}$, $\left.\mathrm{CH}_{2} \mathrm{~N}\right) ; 5.83(\mathrm{bs}, 1 \mathrm{H}, \mathrm{OH}) ; 6.68(\mathrm{~d}, 1 \mathrm{H}, 7-\mathrm{C} \mathrm{CH}$ in isatin, $J=7.3) ; 7.05(\mathrm{t}, 1 \mathrm{H}, 5-\mathrm{C} \mathrm{CH}$ in isatin, $J=8.1)$; $7.46(t, 1 \mathrm{H}, 6-\mathrm{C} \mathrm{CH}$ in isatin, $J=8.1) ; 7.56(\mathrm{~d}, 1 \mathrm{H}, 4-\mathrm{C}$ in isatin, $J=7.3) ; 7.83(\mathrm{~s}, 2 \mathrm{H}, \mathrm{Ar}) . \mathrm{NMR}^{13} \mathrm{C}$ 
(DMSO-d ${ }_{6}, \delta$, ppm): $30.1\left(2\left(\mathrm{CH}_{3}\right)_{3}\right) ; 34.5 ; 46.1\left(\mathrm{CH}_{2} \mathrm{~N}\right) ; 109.6 ; 110.8 ; 117.7 ; 123.9 ; 125.4 ; 126.1 ; 136.5$; 138.4; 151.2; 158.5 (10 Ar); 159.6 ( $\mathrm{C}=\mathrm{O} 2-\mathrm{C}$ in isatin); 181.6 ( $\mathrm{C}=\mathrm{O} 3-\mathrm{C}$ in isatin); 196.7 ( $\mathrm{C}=\mathrm{O})$. Elemental analysis found: $\mathrm{C}, 73.18 ; \mathrm{H}, 7.05 ; \mathrm{N}, 3.38$. Calculated for $\mathrm{C}_{24} \mathrm{H}_{27} \mathrm{NO}_{4}: \mathrm{C}, 73.26 ; \mathrm{H}, 6.92 ; \mathrm{N}, 3.56$.

1-[2-(3,5-Di-tert-butyl-4-hydroxyphenyl)-2-oxoethyl]pyrrolidin-2,5-dione5. White solid. Yield 74\%. m.p. 259-260 ${ }^{\circ} \mathrm{C}$ (acetonitrile). NMR ${ }^{1} \mathrm{H}\left(\mathrm{CDCl}_{3}, \delta, \mathrm{ppm}, 3 \mathrm{JHH}, \mathrm{Hz}\right): 1.47\left(\mathrm{~s}, 18 \mathrm{H}, 2\left(\mathrm{CH}_{3}\right)_{3}\right) ; 2.86(\mathrm{~s}, 4 \mathrm{H}$, $2 \mathrm{CH}_{2}$ in imide); 4.93 (s, $\left.2 \mathrm{H}, \mathrm{CH}_{2} \mathrm{~N}\right) ; 5.83$ (bs, $\left.1 \mathrm{H}, \mathrm{OH}\right) ; 7.85$ (s, $\left.2 \mathrm{H}, \mathrm{Ar}\right) . \mathrm{NMR}^{13} \mathrm{C}\left(\mathrm{CDCl}_{3}, \delta, \mathrm{ppm}\right): 28.4$ (2 $\mathrm{CH}_{2}$ in imide); $30.1\left(2\left(\mathrm{CH}_{3}\right)_{3}\right) ; 34.4 ; 44.5\left(\mathrm{CH}_{2} \mathrm{~N}\right) ; 109.6 ; 125.9 ; 136.9 ; 159.3(4 \mathrm{Ar}) ; 176.8(2 \mathrm{C}=\mathrm{O}$ in imide); $189.2(\mathrm{C}=\mathrm{O})$. Elemental analysis found: $\mathrm{C}, 69.37 ; \mathrm{H}, 7.97 ; \mathrm{N}, 3.95$. Calculated for $\mathrm{C}_{20} \mathrm{H}_{27} \mathrm{NO}_{4}$ : C, 69.54; H, 7.88; N, 4.05 .

\subsubsection{Synthesis of Compounds 6,7 .}

A solution of bromoacetophenone 1 ( $3 \mathrm{mmol})$ with uracil or 5 -metyluracil $(3 \mathrm{mmol})$ and anhydrous $\mathrm{K}_{2} \mathrm{CO}_{3}(9 \mathrm{mmol})$ was stirred for $4 \mathrm{~h}$ at $70{ }^{\circ} \mathrm{C}$ in $15 \mathrm{~mL}$ of DMF. After cooling, reaction mixture was poured into water and the precipitate was filtered off. The precipitate was refluxed in hexane, and then dissolved in acetone. The unsolved part was filtered off, and acetone was evaporated under residue pressure to give crystalline product, which was recrystallized from an appropriate solvent.

1-(2-(3,5-Di-tert-butyl-4-hydroxyphenyl)-2-oxoethyl)pyrimidine-2,4(1H,3H)-dione6. Yellow solid. Yield 52\%.

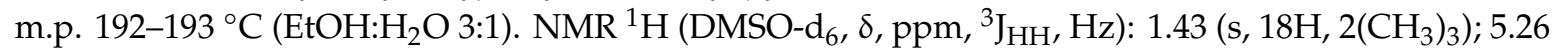
$(\mathrm{d}, 1 \mathrm{H}, \mathrm{CH}$ in uracil, $J=3.9) ; 5.61(\mathrm{~d}, 1 \mathrm{H}, \mathrm{CH}$ in uracil, $J=4.0) ; 7.53(\mathrm{~s}, 1 \mathrm{H}, \mathrm{OH}) ; 7.77(\mathrm{~s}, 2 \mathrm{H}, \mathrm{Ar}) ; 11.32(\mathrm{~s}$, $\mathrm{NH}) . \mathrm{NMR}^{13} \mathrm{C}\left(\mathrm{DMSO}-\mathrm{d}_{6}, \delta, \mathrm{ppm}\right): 30.4\left(2\left(\mathrm{CH}_{3}\right)_{3}\right) ; 35.0 ; 53.7\left(\mathrm{CH}_{2} \mathrm{~N}\right) ; 101.2 ; 125.6 ; 138.8 ; 146.9 ; 151.6$ $(\mathrm{C}=\mathrm{O}) ; 160.6 ; 164.4(\mathrm{C}=\mathrm{O}) ; 192.0(\mathrm{C}=\mathrm{O})$. Elemental analysis found: $\mathrm{C}, 67.15 ; \mathrm{H}, 7.22 ; \mathrm{N}, 7.68$. Calculated for $\mathrm{C}_{20} \mathrm{H}_{26} \mathrm{~N}_{2} \mathrm{O}_{4}$ : C, 67.02; $\mathrm{H}, 7.31 ; \mathrm{N}, 7.82$.

1-[2-(3,5-Di-tert-butyl-4-hydroxyphenyl)-2-oxoethyl]-5-methylpyrimidin-2,4 $(1 \mathrm{H}, 3 \mathrm{H})$-dione7. Yellow solid. Yield 58\%. m.p. $145-146{ }^{\circ} \mathrm{C}\left(\mathrm{EtOH}: \mathrm{H}_{2} \mathrm{O}\right.$ 2:1). NMR ${ }^{1} \mathrm{H}$ (DMSO-d6, $\delta$, ppm, $\left.{ }^{3} \mathrm{~J}_{\mathrm{HH}}, \mathrm{Hz}\right): 1.43$ (s, 18H, $\left.2\left(\mathrm{CH}_{3}\right)_{3}\right) ; 1.77\left(\mathrm{~s}, 3 \mathrm{H}, \mathrm{CH}_{3}\right) ; 5.22\left(\mathrm{~s}, 2 \mathrm{H}, \mathrm{CH}_{2} \mathrm{~N}\right) ; 7.42(\mathrm{~s}, 1 \mathrm{H}, \mathrm{CH}-\mathrm{N}) ; 7.77(\mathrm{~s}, 2 \mathrm{H}, \mathrm{Ar}) ; 7.99(\mathrm{~s}, 1 \mathrm{H}, \mathrm{OH})$; $11.31(\mathrm{~s}, 1 \mathrm{H}, \mathrm{NH}) . \mathrm{NMR}^{13} \mathrm{C}\left(\mathrm{DMSO}-\mathrm{d}_{6}, \delta, \mathrm{ppm}\right): 12.4\left(\mathrm{CH}_{3}\right) ; 30.41\left(2\left(\mathrm{CH}_{3}\right)_{3}\right) ; 35.0 ; 53.6\left(\mathrm{CH}_{2} \mathrm{~N}\right) ; 108.7$; 125.6; 126.3; 138.9; 142.6; $151.6(\mathrm{C}=\mathrm{O}) ; 160.0 ; 164.9(\mathrm{C}=\mathrm{O}) ; 192.4(\mathrm{C}=\mathrm{O})$. Elemental analysis found: $\mathrm{C}$, 67.82; $\mathrm{H}, 7.74 ; \mathrm{N}, 7.50$. Calculated for $\mathrm{C}_{21} \mathrm{H}_{28} \mathrm{~N}_{2} \mathrm{O}_{4}$ : C, 67.72; $\mathrm{H}, 7.58 ; \mathrm{N}, 7.52$.

\subsubsection{Synthesis of Compounds $\mathbf{9 a - c .}$}

A mixture of aldehyde $8(4 \mathrm{mmol})$, urea or thiourea $(8 \mathrm{mmol})$ and appropriate dicarbonyl compound (5.2 mmol), was dissolved in $13 \mathrm{~mL}$ of ethanol. Then, $\mathrm{FeCl}_{3} \bullet 6 \mathrm{H} 2 \mathrm{O}(4 \mathrm{mmol})$ was added to the mixture as a catalyst. The reaction proceeded for $18 \mathrm{~h}$; its progress was monitored by TLC. After cooling the reaction mixture, a precipitate formed which was filtered under vacuum, washed with benzene, and recrystallized from an appropriate solvent.

Ethyl-4-(3,5-di-tert-butyl-4-hydroxyphenyl)-6-methyl-2-oxo-1,2,3,4-tetrahydro-pyrimidine-5-carboxylate 9a. White solid. Yield 55\%. m.p. $227-228{ }^{\circ} \mathrm{C}\left(\mathrm{EtOH}: \mathrm{H}_{2} \mathrm{O} 4: 1\right) . \mathrm{NMR}{ }^{1} \mathrm{H}\left(\mathrm{CDCl}_{3}, \delta, \mathrm{ppm},{ }^{3} \mathrm{~J}_{\mathrm{HH}}, \mathrm{Hz}\right): 1.11(t$, $3 \mathrm{H}, \mathrm{CH}_{3}, J=7.1 \mathrm{~Hz}$ ); $1.41(\mathrm{~s}, 18 \mathrm{H}, t-\mathrm{Bu}) ; 2.27\left(\mathrm{~s}, 3 \mathrm{H}, \mathrm{CH}_{3}\right) ; 4.02\left(\mathrm{q}, 2 \mathrm{H}, \mathrm{CH}_{2}, J=7.1 \mathrm{~Hz}\right.$ ); $5.12(\mathrm{~s}, 1 \mathrm{H}$, $\mathrm{CH}) ; 5.80(\mathrm{~s}, 1 \mathrm{H}, \mathrm{OH}) ; 7.03(\mathrm{~s}, 2 \mathrm{H}, \mathrm{Ar}) ; 7.66(\mathrm{~s}, 1 \mathrm{H}, \mathrm{NH}) ; 9.78(\mathrm{~s}, 1 \mathrm{H}, \mathrm{NH}) . \mathrm{NMR}^{13} \mathrm{C}\left(\mathrm{CDCl}_{3}, \delta, \mathrm{ppm}\right)$ : $14.2 ; 18.6 ; 30.2 ; 34.3 ; 55.7 ; 59.9 ; 102.0,123.1 ; 134.6 ; 136.0 ; 145.8 ; 153.4 ; 162.3$, 165.9. Elemental analysis found: $\mathrm{C}, 68.11 ; \mathrm{H}, 8.48 ; \mathrm{N}, 7.13$. Calculated for $\mathrm{C}_{22} \mathrm{H}_{32} \mathrm{~N}_{2} \mathrm{O}_{4}: \mathrm{C}, 68.01 ; \mathrm{H}, 8.30 ; \mathrm{N}, 7.21$.

Ethyl-4-(3,5-di-tert-butyl-4-hydroxyphenyl)-6-methyl-2-thioxo-1,2,3,4-tetrahydro-pyrimidine-5-carboxylate $\mathbf{9 b}$. White solid. Yield 61\%. m.p. $235-237^{\circ} \mathrm{C}\left(\mathrm{EtOH}: \mathrm{H}_{2} \mathrm{O} 2: 1\right) . \quad \mathrm{NMR}{ }^{1} \mathrm{H}\left(\mathrm{CDCl}_{3}, \delta, \mathrm{ppm},{ }^{3} \mathrm{~J}_{\mathrm{HH}}, \mathrm{Hz}\right)$ : $1.11\left(t, 3 \mathrm{H}, \mathrm{CH}_{3}, J=7.1 \mathrm{~Hz}\right) ; 1.34(\mathrm{~s}, 18 \mathrm{H}, t-\mathrm{Bu}) ; 2.37\left(\mathrm{~s}, 3 \mathrm{H}, \mathrm{CH}_{3}\right) ; 4.12\left(\mathrm{q}, 2 \mathrm{H}, \mathrm{CH}_{2}, J=7.1 \mathrm{~Hz}\right.$ ); $5.24(\mathrm{~s}, 1 \mathrm{H}, \mathrm{CH}) ; 5.35(\mathrm{~s}, 1 \mathrm{H}, \mathrm{OH}) ; 7.01(\mathrm{~s}, 2 \mathrm{H}, \mathrm{Ar}) ; 7.38(\mathrm{~s}, 1 \mathrm{H}, \mathrm{NH}) ; 8.13(\mathrm{~s}, 1 \mathrm{H}, \mathrm{NH}) . \mathrm{NMR}^{13} \mathrm{C}\left(\mathrm{CDCl}_{3}\right.$, 
ס, ppm): $14.2 ; 18.2 ; 30.2 ; 3.3 ; 56.2 ; 60.3 ; 103.6 ; 123.4 ; 128.4 ; 133.2 ; 136.2 ; 142.4 ; 153.8 ; 165.5$. Elemental analysis found: $\mathrm{C}, 65.15 ; \mathrm{H}, 8.08 ; \mathrm{N}, 6.77 ; \mathrm{S}, 7.82$. Calculated for $\mathrm{C}_{22} \mathrm{H}_{32} \mathrm{~N}_{2} \mathrm{O}_{3} \mathrm{~S}: \mathrm{C}, 65.31 ; \mathrm{H}, 7.97 ; \mathrm{N}$, $6.92 ; \mathrm{S}, 7.92$.

1-(4-(3,5-Di-tert-butyl-4-hydroxyphenyl)-6-methyl-2-thioxo-1,2,3,4-tetrahydropyrimidin-5-yl)ethan-1-one 9c. White solid. Yield 64\%. m.p. $204-206{ }^{\circ} \mathrm{C}\left(\mathrm{EtOH}: \mathrm{H}_{2} \mathrm{O} 4: 1\right)$. NMR ${ }^{1} \mathrm{H}\left(\mathrm{DMSO}-\mathrm{d}_{6}, \delta, \mathrm{ppm},{ }^{3} \mathrm{~J}_{\mathrm{HH}}, \mathrm{Hz}\right)$ : $1.41(\mathrm{~s}, 18 \mathrm{H}, t-\mathrm{Bu}) ; 1.48\left(\mathrm{~s}, 3 \mathrm{H}, \mathrm{CH}_{3}\right) ; 5.26(\mathrm{~s}, 1 \mathrm{H}, \mathrm{CH}) ; 7.05(\mathrm{~s}, 1 \mathrm{H}, \mathrm{OH}) ; 7.36(\mathrm{~s}, 2 \mathrm{H}, \mathrm{Ar}) ; 7.73(\mathrm{~s}, 1 \mathrm{H}, \mathrm{NH})$; 8.03 (s, 1H, NH). $\mathrm{NMR}^{13} \mathrm{C}\left(\mathrm{DMSO}_{-} \mathrm{d}_{6}, \delta, \mathrm{ppm}\right): 19.4 ; 30.1 ; 30.2 ; 34.4 ; 56.8 ; 111.7 ; 123.7 ; 128.4 ; 132.2$; 136.6; 141.6; 154.1; 195.8. Elemental analysis found: $\mathrm{C}, 67.44 ; \mathrm{H}, 8.25 ; \mathrm{N}, 7.36 ; \mathrm{S}, 8.47$ Calculated for $\mathrm{C}_{21} \mathrm{H}_{30} \mathrm{~N}_{2} \mathrm{O}_{2} \mathrm{~S}: \mathrm{C}, 67.34 ; \mathrm{H}, 8.07 ; \mathrm{N}, 7.48 ; \mathrm{S}, 8.56$.

\subsection{Redox Properties}

Cyclic voltammetry (CV) was carried out in the argon atmosphere in a three-electrode cell using an Ecotest-VA potentiostat (Moscow, Russia). The working electrode was a stationary platinum electrode $\mathrm{S}=$ of $3 \mathrm{~mm}^{2}$; the auxiliary electrode was a platinum plate $\left(\mathrm{S}=18 \mathrm{~mm}^{2}\right)$. The reference electrode was $(\mathrm{Ag} / \mathrm{AgCl} / \mathrm{KCl})$, with a waterproof diaphragm. The potential sweep rate was $0.2 \mathrm{~V} \cdot \mathrm{s}^{-1} \cdot \mathrm{Et}_{4} \mathrm{NClO}_{4}(99 \%$, Acros) for the supporting electrolyte was twice recrystallized from the aqueous ethanol and dried for $48 \mathrm{~h}$ in vacuum at $50{ }^{\circ} \mathrm{C}$. The concentration of the studied compounds was $5 \mathrm{mM}$.

\subsection{Biological Activity}

Antimicrobial screening was performed by CO-ADD (The Community for Antimicrobial Drug Discovery), funded by the Wellcome Trust (London, UK) and The University of Queensland (Brisbane, Australia). The antimicrobial activities were evaluated against cultures of Staphylococcus aureus ATCC 43300, Escherichia coli ATCC 25922, Klebsiella pneumoniae ATCC 700603, Acinetobacter baumannii ATCC 19606, and Pseudomonas aeruginosa ATCC 27853. Compounds were plated as a 2-fold dose response from 32 to $0.25 \mu \mathrm{g} / \mathrm{mL}$ (or 20 to $0.156 \mathrm{uM}$ ), with a maximum of $0.5 \%$ DMSO, final in assay concentration. The growth inhibition of all bacteria was determined measuring absorbance at $600 \mathrm{~nm}$ (OD600), using a Tecan M1000 Pro monochromator plate reader. The percentage of growth inhibition was calculated for each well, using the negative control (media only) and positive control (bacteria without inhibitors) on the same plate as references. The minimum inhibitory concentration (MIC) was determined following the CLSI guidelines, identifying the lowest concentration at which full inhibition of the bacteria has been detected. Full inhibition of growth has been defined at $<20 \%$ growth (or $>80 \%$ inhibition), and concentrations have only been selected if the next highest concentration displayed full inhibition (i.e., $80-100 \%$ ) as well (eliminating 'singlet' active concentration).

Growth inhibition of HEK293 cells was determined measuring fluorescence at ex:530/10 nm and em:590/10 $\mathrm{nm}$ ( $\mathrm{F560/590)}$, after the addition of resazurin $(25 \mu \mathrm{g} / \mathrm{mL}$ final concentration) and incubation at $37{ }^{\circ} \mathrm{C}$ and $5 \% \mathrm{CO}_{2}$, for an additional $3 \mathrm{~h}$. The fluorescence was measured using a Tecan M1000 Pro monochromator plate reader. The percentage of growth inhibition was calculated for each well, using the negative control (media only) and positive control (cell culture without inhibitors) on the same plate as references.

\section{Conclusions}

In this study, the synthesis, redox properties and anibacterial activity of nine 2,6-di-tert-buthylphenol derivatives linked to different heterocycles are described. For uracil and thymine, it is revealed by 2D-NMR spectroscopy that substitution takes place at the N-1 atom. Electrochemical studies of obtained compounds show, that the nature of the substituent in the 4th position of the phenolic ring strongly influences on the antioxidant activity. Compounds 2-5 with an electron-withdrawing linker between heterocycle and phenol showed a shift in the oxidation potential to the positive region, but its values are still comparable to those of BHT. 
Dihydropyrimidines $\mathbf{9 a - c}$, in which the heterocycle was connected with phenol, directly showed lower value of oxidation potential and higher antioxidant abilities. Studies of antibacterial properties showed that $\mathrm{N}$-(2-(3,5-di-tert-butyl-4-hydroxyphenyl)-2-oxoethyl)isatin 4 is active against Staphylococcus aureus in concentration $32 \mu \mathrm{g} / \mathrm{mL}$, with a low toxicity against human cells. Thus, compound 4 was found to be the multipotent antioxidant.

Supplementary Materials: ${ }^{1} \mathrm{H}-\mathrm{NMR}$ and ${ }^{13} \mathrm{C}-\mathrm{NMR}$ spectra of obtained compounds.

Author Contributions: O.V.P., concept, performing chemical synthesis and purification, spectroscopy experiments, writing manuscript. S.V.V., analyzing spectroscopy data, writing manuscript. L.V.I., electrochemical experiments, analyzing data, writing manuscript. V.N.K., concept, supervision, writing manuscript. All authors have read and agreed to the published version of the manuscript.

Funding: This research received no external funding.

Conflicts of Interest: The authors declare no conflict of interest.

\section{References}

1. Gandhi, S.; Abramov, A.Y. Mechanism of oxidative stress in neurodegeneration. Oxidative Med. Cell. Longev. 2012. [CrossRef]

2. Mezeiova, E.; Spilovska, K.; Nepovimova, E.; Gorecki, L.; Soukup, O.; Dolezal, R.; Malinak, D.; Janockova, J.; Jun, D.; Kuca, K. Profiling donepezil template into multipotent hybrids with antioxidant properties. J. Enzym. Inhib. Med. Chem. 2018, 33, 583-606. [CrossRef]

3. Hanikoglu, A.; Ozben, H.; Hanikoglu, F.; Ozben, T. Hybrid compounds \& oxidative stress induced apoptosis in cancer therapy. Curr. Med. Chem. 2020, 27, 2118-2132.

4. Gyurászová, M.; Gurecká, R.; Bábíčková, J.; Tóthová, L. Oxidative stress in the pathophysiology of kidney disease: Implications for noninvasive monitoring and identification of biomarkers. Oxidative Med. Cell. Longev. 2020. [CrossRef]

5. Yehye, W.A.; Rahman, N.A.; Ariffin, A.; Hamid, S.B.A.; Alhadi, A.A.; Kadir, F.A.; Yaeghoobi, M. Understanding the chemistry behind the antioxidant activities of butylated hydroxytoluene (BHT): A review. Eur. J. Med. Chem. 2015, 101, 295-312. [CrossRef] [PubMed]

6. Osipova, V.; Antonova, N.; Berberova, N.; Poddel'skii, A.; Kudryavtsev, K. Redox properties of novel pyrrolidine derivatives containing sterically hindered phenol fragment. Russ. J. Electrochem. 2011, 47, 1119. [CrossRef]

7. Koltover, V. Antioxidant biomedicine: From free radical chemistry to systems biology mechanisms. Russ. Chem. Bull. 2010, 59, 37-42. [CrossRef]

8. Wang, W.; Kannan, P.; Xue, J.; Kannan, K. Synthetic phenolic antioxidants, including butylated hydroxytoluene (BHT), in resin-based dental sealants. Environ. Res. 2016, 151, 339-343. [CrossRef] [PubMed]

9. White, I.R.; Lovell, C.R.; Cronin, E. Antioxidants in cosmetics. Contact Dermat. 1984, 11, 265-267. [CrossRef] [PubMed]

10. Babich, H. Butylated hydroxytoluene (BHT): A review. Environ. Res. 1982, 29, 1-29. [CrossRef]

11. Koshelev, V.; Kelarev, V.; Belov, N. Effect of azoles and sym-triazines with hindered phenol fragments on protective properties of turbine oils. Chem. Technol. Fuels Oils 1995. [CrossRef]

12. Latyuk, V.; Kelarev, V.; Koshelev, V.; Korenev, K. Sulfides of the sym-Triazine series as oil—Soluble corrosion inhibitors. Chem. Technol. Fuels Oils 2002, 38, 312-315. [CrossRef]

13. Milaeva, E.R.; Shpakovsky, D.B.; Gracheva, Y.A.; Orlova, S.I.; Maduar, V.V.; Tarasevich, B.N.; Meleshonkova, N.N.; Dubova, L.G.; Shevtsova, E.F. Metal complexes with functionalised 2,2'-dipicolylamine ligand containing an antioxidant 2,6-di-tert-butylphenol moiety: Synthesis and biological studies. Dalton Trans. 2013, 42, 6817-6828. [CrossRef] [PubMed]

14. Mikhalev, O.; Shpakovsky, D.; Gracheva, Y.A.; Antonenko, T.; Albov, D.; Aslanov, L.; Milaeva, E. Synthesis and study of new phenolic antioxidants with nitroaromatic and heterocyclic substituents. Russ. Chem. Bull. 2018, 67, 712-720. [CrossRef]

15. Zhang, H.-Y. Structure-activity relationships and rational design strategies for radical-scavenging antioxidants. Curr. Comput. Aided Drug Des. 2005, 1, 257-273. [CrossRef]

16. Zhang, H.-Y.; Yang, D.-P.; Tang, G.-Y. Multipotent antioxidants: From screening to design. Drug Discov. Today 2006, 11, 749-754. [CrossRef] 
17. Mullican, M.D.; Wilson, M.W.; Conner, D.T.; Kostlan, C.R.; Schrier, D.J.; Dyer, R.D. Design of 5-(3,5-di-tert-butyl-4-hydroxyphenyl)-1,3,4-thiadiazoles,-1,3,4-oxadiazoles, and-1,2,4-triazoles as orally active, nonulcerogenic antiinflammatory agents. J. Med. Chem. 1993, 36, 1090-1099. [CrossRef]

18. Chłon-Rzepa, G.; Jankowska, A.W.; Zygmunt, M.; Pociecha, K.; Wyska, E. Synthesis of 8-alkoxy-1,3-dimethyl2,6-dioxopurin-7-yl-substituted acetohydrazides and butanehydrazides as analgesic and anti-inflammatory agents. Heterocycl. Commun. 2015, 21, 273-278. [CrossRef]

19. Isomura, Y.; Sakamoto, S.; Ito, N.; Homma, H.; Abe, T.; Kubo, K. Synthesis and anti-inflammatory activity of 2,6-di-tertbutylphenols with a heterocyclic group at the 4-position. III. Chem. Pharm. Bull. 1984, 32, 152-165. [CrossRef]

20. Kuchana, M.; Bethapudi, D.R.; Ediga, R.K.; Sisapuram, Y. Synthesis, in-vitro antioxidant activity and in-silico prediction of drug-likeness properties of a novel compound: 4-(3,5-Di-tert-butyl4-hydroxybenzylidene)-3-methylisoxazol-5(4H)-one. J. Appl. Pharm. Sci. 2019, 9, 105-110.

21. Gibadullina, E.; Nguyen, T.T.; Strelnik, A.; Sapunova, A.; Voloshina, A.; Sudakov, I.; Vyshtakalyuk, A.; Voronina, J.; Pudovik, M.; Burilov, A. New 2,6-diaminopyridines containing a sterically hindered benzylphosphonate moiety in the aromatic core as potential antioxidant and anti-cancer drugs. Eur. J. Med. Chem. 2019, 184, 111735. [CrossRef]

22. Ahmad, M.H.; Rahman, N.A.; Kadir, F.A.; Al-Ani, L.A.; Hashim, N.M.; Yehye, W.A. Design and synthesis of sulfur-containing butylated hydroxytoluene: Antioxidant potency and selective anticancer agent. J. Chem. Sci. 2019, 131, 107. [CrossRef]

23. Alsultan, Q.M.N.; Sijam, K.; Rashid, T.S.; Ahmad, K.B. GC-MS Analysis and antibacterial activity of mangosteen leaf extracts against plant pathogenic bacteria. Am. J. Plant Sci. 2016, 7, 1013. [CrossRef]

24. Madkour, H.M.; Ghareeb, M.A.; Abdel-Aziz, M.S.; Khalaf, O.M.; Saad, A.M.; El-Ziaty, A.K.; Abdel-Mogib, M. Gas chromatography-mass spectrometry analysis, antimicrobial, anticancer and antioxidant activities of n-hexane and methylene chloride extracts of Senna italica. J. Appl. Pharm. Sci. 2017, 7, 23-32.

25. Zhao, F.; Wang, P.; Lucardi, R.D.; Su, Z.; Li, S. Natural sources and bioactivities of 2,4-di-tert-butylphenol and its analogs. Toxins 2020, 12, 35. [CrossRef] [PubMed]

26. Zhang, T.; Wei, X.; Miao, Z.; Hassan, H.; Song, Y.; Fan, M. Screening for antioxidant and antibacterial activities of phenolics from Golden Delicious apple pomace. Chem. Cent. J. 2016, 10, 47. [CrossRef]

27. Turcotte, P.; Saheb, S. Antimicrobial activity of phenolic antioxidants. Can. J. Microbiol. 1978, 24, 1306-1320. [CrossRef]

28. Seven, O.; Dindar, B.; Aydemir, S.; Cilli, F. Synthesis, properties and photodynamic activities of some zinc (II) phthalocyanines against Escherichia coli and Staphylococcus aureus. J. Porphyr. Phthalocyanines 2008, 12, 953-963. [CrossRef]

29. Dindar, B.; Ince, M.; Seven, Ö. Synthesis, characterization and the photodynamic activity against some gram negative and positive bacteria of novel Subphthalocyanine derivative. Gazi Univ. J. Sci. 2013, 26, 1-10.

30. Ganji, N.; Rambabu, A.; Vamsikrishna, N.; Daravath, S. Copper (II) complexes with isoxazole Schiff bases: Synthesis, spectroscopic investigation, DNA binding and nuclease activities, antioxidant and antimicrobial studies. J. Mol. Struct. 2018, 1173, 173-182. [CrossRef]

31. Ammar, V.A.; Gres'ko, S.; Kelarev, V.; Koshelev, V. $\Delta 2$-imidazoline derivatives in molecular design of condensed heterocycles with fragments of space-hindered phenol. ИзвестияВысших Учебных Заведений Химия и Химическая Технология 2007, 50, 105-109.

32. Popov, L.; Levchenkov, S.; Zubenko, A.; Shcherbakov, I.; Fetisov, L.; Bodryakov, A.; Maevskii, O.; Kogan, V. Synthesis, protistocidal and antibacterial activities of 2 '-imidazolinylhydrazones of mono-and dicarboxylic acids. Pharm. Chem. J. 2015, 49, 21-23. [CrossRef]

33. Kong, C.; Yehye, W.A.; Rahman, N.A.; Tan, M.-W.; Nathan, S. Discovery of potential anti-infectives against Staphylococcus aureus using a Caenorhabditis elegans infection model. BMC Complementary Altern. Med. 2014, 14, 4. [CrossRef] [PubMed]

34. Hall, C.D.; Panda, S.S. The benzotriazole story. In Advances in Heterocyclic Chemistry; Elsevier: Amsterdam, The Netherlands, 2016; Volume 119, pp. 1-23.

35. Matijević-Sosa, J.; Cvetnić, Z. Antimicrobial activity of N-phthaloylamino acid hydroxamates. Acta Pharm. 2005, 55, 387-399.

36. Cvetković, J.P.; Božić, B.Đ.; Banjac, N.R.; Petrović, J.; Soković, M.; Vitnik, V.D.; Vitnik, Ž.J.; Ušćumlić, G.S.; Valentić, N.V. Synthesis, antimicrobial activity and quantum chemical investigation of novel succinimide derivatives. J. Mol. Struct. 2019, 1181, 148-156. [CrossRef] 
37. Lian, Z.-M.; Sun, J.; Zhu, H.-L. Design, synthesis and antibacterial activity of isatin derivatives as FtsZ inhibitors. J. Mol. Struct. 2016, 1117, 8-16. [CrossRef]

38. Ha, E.-M. Escherichia coli-derived uracil increases the antibacterial activity and growth rate of Lactobacillus plantarum. J. Microbiol. Biotechnol 2016, 26, 975-987. [CrossRef]

39. Gao, F.; Ye, L.; Kong, F.; Huang, G.; Xiao, J. Design, synthesis and antibacterial activity evaluation of moxifloxacin-amide-1,2,3-triazole-isatin hybrids. Bioorganic Chem. 2019, 91, 103162. [CrossRef]

40. Bettencourt, A.; Castro, M.; Silva, J.; Fernandes, F.; Coutinho, O.; Sousa, M.J.; Proença, M.F.; Areias, F. New nitrogen compounds coupled to phenolic units with antioxidant and antifungal activities: Synthesis and structure-Activity relationship. Molecules 2018, 23, 2530. [CrossRef]

41. Parker, D.K. Process for Preparing Hindered Alkenyl Phenols. U.S. Patent US4072724A, 7 February 1978.

42. Zhang, K.; Corrie, J.E.; Munasinghe, V.R.N.; Wan, P. Mechanism of photosolvolytic rearrangement of p-hydroxyphenacyl esters: Evidence for excited-state intramolecular proton transfer as the primary photochemical step. J. Am. Chem. Soc. 1999, 121, 5625-5632. [CrossRef]

43. Qu, G.; Zhang, Z.; Guo, H.; Geng, M.; Xia, R. Microwave-promoted facile and efficient preparation of $\mathrm{N}$-(alkoxycarbonylmethyl) nucleobases-Building blocks for peptide nucleic acids. Molecules 2007, 12, 543-551. [CrossRef] [PubMed]

44. Hu, E.H.; Sidler, D.R.; Dolling, U.-H. Unprecedented catalytic three component one-pot condensation reaction: An efficient synthesis of 5-alkoxycarbonyl-4-aryl-3,4-dihydropyrimidin-2(1H)-ones. J. Org. Chem. 1998, 63, 3454-3457. [CrossRef]

45. Aslanoğlu, F.; Akbaş, E.; Sönmez, M.; Anıl, B. Studies on reactions of pyrimidine compounds: Synthesis and reactions of 5-benzoyl-4,6-diphenyl-1,2,3,4-tetrahydro-2-thioxopyrimidine. Phosphorus Sulfur Silicon Relat. Elem. 2007, 182, 1589-1597. [CrossRef]

46. Mohammadizadeh, M.R.; Firoozi, N. Trifluoroacetic acid as an effective catalyst for Biginelli reaction: One-pot, three-component synthesis of 3,4-dihydropyrimidin-2(1H)-ones (and-thiones). J. Chem. 2011, 8, S266-S270. [CrossRef]

47. Lu, J.; Bai, Y.J.; Guo, Y.H.; Wang, Z.J.; Ma, H.R. $\mathrm{CoCl}_{2} \cdot 6 \mathrm{H}_{2} \mathrm{O}$ or $\mathrm{LaCl}_{3} \cdot 7 \mathrm{H}_{2} \mathrm{O}$ catalyzed Biginelli reaction. One-pot synthesis of 3,4-dihydropyrimidin-2(1H)-ones. Chin. J. Chem. 2002, 20, 681-687. [CrossRef]

48. Lu, J.; Bai, Y. Catalysis of the Biginelli reaction by ferric and nickel chloride hexahydrates. One-pot synthesis of 3,4-dihydropyrimidin-2(1H)-ones. Synthesis 2002. [CrossRef]

49. Sabitha, G.; Reddy, G.K.K.; Reddy, C.S.; Yadav, J. One-pot synthesis of dihydropyrimidinones using iodotrimethylsilane. Facile and new improved protocol for the Biginelli reaction at room temperature. Synlett 2003. [CrossRef]

50. Sedova, V.; Krivopalov, V.; Shkurko, O. Synthesis of substituted 3,4-dihydropyrimidin-2(1H)-ones and pyrimidin-2 $(1 H)$-ones by the Biginelli reaction with 3,5-Di-tert-butyl-4-hydroxybenzaldehyde. Russ. J. Org. Chem. 2009, 45, 1535. [CrossRef]

51. Javanmardi, J.; Stushnoff, C.; Locke, E.; Vivanco, J. Antioxidant activity and total phenolic content of Iranian Ocimum accessions. Food Chem. 2003, 83, 547-550. [CrossRef]

52. Chevion, S.; Roberts, M.A.; Chevion, M. The use of cyclic voltammetry for the evaluation of antioxidant capacity. Free Radic. Biol. Med. 2000, 28, 860-870. [CrossRef]

53. Tyurin, V.Y.; Wu, Y.; Dolganov, A.; Milaeva, E. Antioxidant activity assay of 2,6-di-tert-butylphenols with phosphonate groups using cyclic voltammetry. In Doklady Chemistry; SP MAIK Nauka/Interperiodica: Moscow, Russia, 2011; Volume 436, pp. 31-33.

54. Tyurin, V.Y.; Yaohuan, W.; Prishchenko, A.; Shpakovsky, D.; Gracheva, Y.A.; Antonenko, T.; Tafeenko, V.; Al, D.; Aslanov, L.; Milaeva, E. Complexes of organotin compounds with bis-and trisphosphonate derivatives of 2, 6-di-tert-butylphenol having antioxidant activity. Russ. Chem. Bull. 2015, 64, 1419-1429. [CrossRef]

55. Gil, E.d.S.; Andrade, C.H.; Barbosa, N.L.; Braga, R.C.; Serrano, S.H. Cyclic voltammetry and computational chemistry studies on the evaluation of the redox behavior of parabens and other analogues. J. Braz. Chem. Soc. 2012, 23, 565-572. [CrossRef]

56. Simić, A.; Manojlović, D.; Šegan, D.; Todorović, M. Electrochemical behavior and antioxidant and prooxidant activity of natural phenolics. Molecules 2007, 12, 2327-2340. [CrossRef] [PubMed]

57. Enache, T.A.; Oliveira-Brett, A.M. Phenol and para-substituted phenols electrochemical oxidation pathways. J. Electroanal. Chem. 2011, 655, 9-16. [CrossRef] 
58. Sridhar, S.K.; Saravanan, M.; Ramesh, A. Synthesis and antibacterial screening of hydrazones, Schiff and Mannich bases of isatin derivatives. Eur. J. Med. Chem. 2001, 36, 615-625. [CrossRef]

59. Ma, T.; Chen, R.; Xue, H.; Miao, Z.; Chen, L.; Zhang, H.; Shi, X. Di-isatin heteronuclear compounds and their antibacterial activity. J. Heterocycl. Chem. 2020, 57, 503-509. [CrossRef]

Sample Availability: Samples of the compounds 1-9a-c are available from the authors.

(C) 2020 by the authors. Licensee MDPI, Basel, Switzerland. This article is an open access article distributed under the terms and conditions of the Creative Commons Attribution (CC BY) license (http://creativecommons.org/licenses/by/4.0/). 